This Accepted Author Manuscript is copyrighted and published by Elsevier. It is posted here by agreement between Elsevier and University of Brasilia. Changes resulting from the publishing process - such as editing, corrections, structural formatting, and other quality control mechanisms - may not be reflected in this version of the text. The definitive version of the text was subsequently published in [Biology of the Cell, Volume 75, 1992, Pages 37-44, doi:10.1016/0248-4900(92)90122-H].You may download, copy and otherwise use the AAM for non-commercial purposes provided that your license is limited by the following restrictions:

(1) You may use this AAM for non-commercial purposes only under the terms of the CC-BY-NCND license.

(2) The integrity of the work and identification of the author, copyright owner, and publisher must be preserved in any copy.

(3) You must attribute this AAM in the following format: [agreed attribution language, including link to CC BY-NC-ND license + Digital Object Identifier link to the published journal article on Elsevier's ScienceDirect ${ }^{\circledR}$ platform].

Este Manuscrito do Autor Aceito para Publicação (AAM) é protegido por direitos autorais e publicado pela Elsevier. Ele esta disponível neste Repositório, por acordo entre a Elsevier e a Universidade de Brasília. As alterações decorrentes do processo de publicação - como a edição, correção, formatação estrutural, e outros mecanismos de controle de qualidade - não estão refletidas nesta versão do texto. A versão definitiva do texto foi posteriormente publicado em [Biology of the Cell, Volume 75, 1992, Páginas 37-44, doi:10.1016/0248-4900(92)90122-H]. Você pode baixar, copiar e utilizar de outra forma o AAM para fins não comerciais, desde que sua licença seja limitada pelas seguintes restrições:

(1) Você pode usar este AAM para fins não comerciais apenas sob os termos da licença CC- BYNC-ND.

(2) A integridade do trabalho e identificação do autor, detentor dos direitos autorais e editor deve ser preservado em qualquer cópia.

(3) Tem de atribuir este AAM no seguinte formato: [acordo na linguagem atribuída, incluindo o link para CC BY-NC-ND licença Digital + DOI do artigo publicado na revista Elsevier ScienceDirect ${ }^{\circledR}$ da plataforma]. 


\title{
Distribution of intramembranous particles and filipin-sterol complexes in the spermatid and spermatozoon ofCulex quinquefasciatus (Culicidae)
}

\author{
Sônia N Báo \\ Wanderley de Souza
}

\begin{abstract}
A freeze-fracture study was carried out on spermatid and spermatozoon of the mosquitoCulex quinquefasciatus. In the spermatid plasma membrane few and randomly distributed intramembranous particles were observed. In the spermatozoon the density of intramembranous particles was higher on the P- than on the E-fracture face of the plasma membrane. Two populations of particles were observed. Large particles (about $15 \mathrm{~nm}$ in diameter) are regularly arranged in double rows as a zipper-line, longitudinally oriented in relation to the main cell axis. These strands of particles were observed in the posterior head region, mainly associated with the E-fracture face. Filipin was used to analyse the presence and distribution of cholesterol in thin sections and freeze-fracture replicas. Filipin-sterol complexes were not homogeneously distributed throughout the spermatozoon plasma membrane. They were more abundant on the P-fracture face of the membrane lining the nuclear region. The results obtained show thatCulex spermatozoon differs from those of other species in that its plasma membrane exhibits only a membrane domain, the zipper-line, localized in the postacrosomal region.
\end{abstract}

Keywords: spermatozoon; freeze-fracture; filipin-sterol complexes; Culex quinquefasciatus

\section{Introduction}

The sperm maturation process involves a series of modifications in its physical, morphological, biochemical and physiological characteristics $[2,3,12,14,27,37]$. Although the various sperm structure undergo distinct changes, probably the most significant modifications occur in the plasma membrane components, as has been shown in the spermatozoon of vertebrates. Its has also been shown that during the maturation and capacitation processes changes on the surface charge $[8,24,25,41]$, exposition of lectin binding sites $[1,4,20,26$, $34]$, antigenic determinants and surface proteins $[7,15,31,33]$ and intramembranous particle distribution [16, 18, 35, 37], take place. There is also strong evidence that alterations in the lipid composition of mammalian spermatozoa occur during their transit through the epididymis $[13,29]$. Content of total phospholipid decreases during maturation in the epididymis. Also the sterol and sterol sulfate contents change during epididymal sperm maturation [22]. The distribution of plasma membrane cholesterol during the maturation and capacitation processes of the vertebrates sperm has been analysed using polyenic antibiotics, including filipin $[11,21,23,28,36,38]$. However, few studies analysed the alterations that occur on the cell surface during insect spermatid differentiation and the capacitation process, 
which take place in the spermatheca $[5,9]$. Recently, we demonstrated that the plasma membrane of Culex quinquefasciatus sperm is asymmetric, presenting a 30-nm thick carbohydrate-containing surface coat which disappears during the sperm storage in the spermatheca [6]. In the present study we used the freeze-fracture technique to examine the distribution of intramembranous particles (IMPs) and filipin-sterol complexes (FSCs) in the plasma membrane of the Culex quinquefasciatus male gamete.

\section{Materials and methods}

The testes and seminal vesicles of male adults, and spermatheca of mated females of Culex quinquefasciatus were obtained from an insect colony maintained in the Department of Entomology of the Instituto Oswaldo Cruz, Rio de Janeiro, Brasil.

Testes, seminal vesicles and spermatheca were dissected and fixed for $2 \mathrm{~h}$ at room temperature in $2.5^{\circ} 70$ glutaraldehyde in $0.1 \mathrm{M}$ cacodylate buffer, $\mathrm{pH} 7.2$, containing or not 100/zg/ml filipin. Filipin (Polysciences) was initially dissolved in dimethyl sulfoxide (DMSO) at a final concentration of $0.5 \%$

For examination of ultrathin sections, the specimens were postfixed in a solution containing 1070 osmium tetroxide, 0.8070 potassium ferricyanide, $5 \mathrm{mM}$ calcium chloride in $0.1 \mathrm{M}$ cacodylate buffer, $\mathrm{pH}$ 7.2. The specimens were dehydrated in acetone and embedded in Epon. For freeze-fracture, the glutaraldehyde and glutaraldehyde-filipin fixed spermatozoa were washed in $0.1 \mathrm{M}$ cacodylate buffer, $\mathrm{pH} 7.2$, and gradually impregnated during $30 \mathrm{~min}$ with glycerol in cacodylate buffer up to a concentration of 30070 , in which they were left for periods varying from 3 to $12 \mathrm{~h}$. Specimens were mounted on Balzer's support disk and rapidly frozen in the liquid phase of partially solidified Freon 22 cooled by liquid-nitrogen. Freezefracture was carried out at $-115^{\circ} \mathrm{C}$ in a Baizer's apparatus. After fracturing, the specimens were platinum-shadowed and carbon-coated. Replicas were cleaned with disodium hypochloride, washed with several changes of distilled water and mounted on 300 mesh grids. Ultrathin sections were stained with uranyl acetate and lead citrate, and were observed in a Zeiss 900 or a Jeol 100 CX transmission electron microscope. 


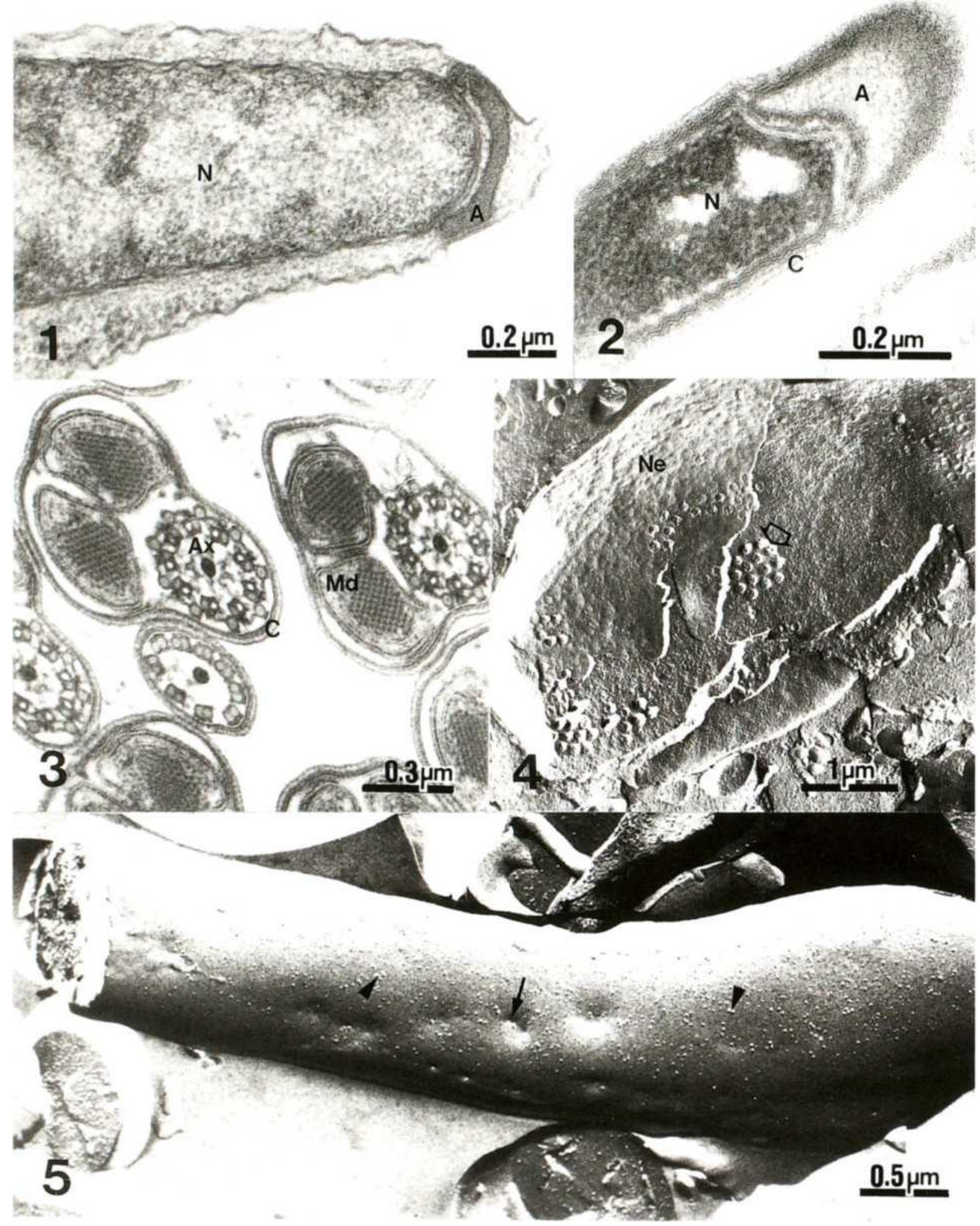

Figs 1 -5.1. Longitudinal section of a differentiating spermatid, showing acrosome (A) and nucleus (N). x 80000. 2. Sagittal section of the spermatozoon head. The surface coat (C) is evident. A: acrosome; $N$ : nucleus, $x$ 112500. 3. Cross section of the spermatozoon tail. The surface coat (C) is evident. Ax: axoneme; Md: mitochondrial derivative, x 80000. 4, 5. Freeze-fracture replicas of mosquito spermatids. 4. Freeze-fracture replica through the nucleus of the spermatid. Nuclear envelope $(\mathrm{Ne})$ displays numerous nuclear pores (arrow) concentrated at some regions, $x 17000$. 5. Freeze-fracture replica of the spermatid showing intramembranous particles (arrowheads) of different sizes randomly distributed throughout the plasma membrane. Depressions (arrow) are observed on the P-fracture face of the plasma membrane, $\mathrm{x}$ 31000 . 


\section{Results}

The Culex quinquefasciatus spermatozoon is a highly differentiated cell, which consists of two morphologically and functionally distinct regions : an elongated rod-like head, which contains the nucleus and the acrosome, and the tail, which is formed by an axoneme and two mitochondrial derivatives containing a crystalline matrix. The centriolar adjunct is located in the anterior portion of the flagellum. The sperm plasma membrane is asymmetric, with its outer surface slightly thickened by an overlying coat (figs 2,3 ), a structure which was not observed on the spermatid (fig 1).

\section{Freeze-fracture}

Freeze-fracture replicas revealed the presence of randomly distributed particles. However, differences were observed in the density and distribution pattern of the intramembranous particles (IMPs) in the sperm membrane.

In initial stages of spermatid differentiation the nuclear envelope presented a large number of nuclear pores. However, they were not homogeneously distributed throughout the membrane, concentrating at some regions (fig 4). The nuclear pores disappeared after chromatin condensation and nuclear elongation. In these stages, the plasma membrane of the spermatid displayed few and randomly distributed intramembranous particles, without evidence of typical particle organization pattern (fig 5).

In the spermatid intramembranous particles of different sizes were randomly distributed throughout its plasma membrane. Some depressions located on the P-fracture face of the plasma membrane of cells in the first stages of spermatid differentiation were seen (fig $5)$. In the last stages of the process of sperm maturation an organized array of particles appeared in the plasma membrane (figs 7-9).

Large (about $15 \mathrm{~nm}$ ) and small (about $9 \mathrm{~nm}$ ) particles could be identified on the P-and E-fracture faces of the plasma membrane of spermatozoan (figs 6 - 9). The density of membrane particles was higher on the P-fracture face (312 + $77 \mathrm{IMP} / / \mathrm{zm} 2)($ fig 9) than on the E-fracture face $\left(162 \_44 \mathrm{IMP} / \sim \mathrm{m}\right.$ 2) (fig 8). The smaller particles predominate, mainly on the P-fracture face (table I). A linear array of large IMPs was observed in a few regions of the Efracture face. The large IMPs appeared in double rows, as a zipper-like line, longitudinally oriented in relation to the main cell axis (fig 8). Usually this zipperline appeared interrupted at several places. Our observations suggest that the linear array of particles is observed in the posterior head portion of the sperm, mainly associated with the E-fracture face of the plasma 
membrane. Very few organized particles were seen on the P-fracture face (figs 7, 9). The IMPs were randomly distributed on the P-and E-fracture faces of the plasma membrane lining the tail regions of the spermatozoon (figs 6,7 ). Occasionally, clusters of particles were observed on the P-face of the plasma membrane (fig 6).

The surface coat of the spermatozoon appeared as two rows of particles in freezefracture replicas (figs 7,10 ).

\section{Filipin treatment}

Examination of thin sections and freeze-fracture replicas showed that the polyenic antibiotic filipin induced changes in the mosquito spermatids plasma membrane. In thin sections of filipin-treated spermatids and spermatozoon it was possible to visualize the characteristic wave configuration induced by the formation of filipin-cholesterol complexes in this membrane. Several hemispherical bulges were observed in the whole spermatid plasma membrane (figs 11 - 16). The majority of the filipin-sterol complexes appeared in the nuclear region of the spermatid head (figs 11 - 14). In contrast, the plasma membrane covering the acrosomal region presented few filipin-sterol complexes (fig 14).

In the tail, the plasma membrane lining the transition zone or the centriolar adjunct region displayed few hemispherical bulges (fig 15). Few filipin-sterol complexes were observed in the membrane lining the flagellum of the early spermatids (fig 16). Filipin-sterol complexes were seen mainly in the membrane lining the head region of the spermatozoa found in the seminal vesicle (fig 17) and in the spermatheca (fig 18).

Filipin-sterol complexes were not seen in internal membranes, such as the acrosomal membrane, mitochondrial derivative membrane, or nuclear membrane (figs 13, 14, 16).

The filipin-sterol complexes were also observed in freezefracture replicas. They appeared as protuberances and/or invaginations on the fracture faces of the plasma membrane. The majority of filipin-sterol complexes appeared as protuberances on the Efracture face and invaginations on the P-fracture face (figs 19, 20). As can be observed in figure 19, the filipin-sterol complexes were densely distributed on the P-fracture face of the head region of the sperm plasma membrane. The density of filipin-sterol complexes was higher on the P-fracture face $(290+10 \mathrm{FSC} / / \mathrm{zm} 2)$ than on the E fracture face $(175+22 \mathrm{FSC} / \sim \mathrm{m} 2)$ of the head region. However, on the flagellum region the filipin-sterol complexes occur in small density (table II). 
Table I. Density of intramembranous particles on the fracture faces of the plasma membrane of the spermatozoon of Culex quinquefasciatus. Values are expressed in number of particles per btm 2 .

\begin{tabular}{lcr}
\hline Types of particles & P-face & \multicolumn{1}{c}{ E-face } \\
\hline Small $(9 \mathrm{~nm})$ & $210 \pm 41$ & $72 \pm 19$ \\
Large $(15 \mathrm{~nm})$ & $102 \pm 36$ & $90 \pm 25$ \\
Total & $312 \pm 77$ & $162 \pm 44$ \\
\hline
\end{tabular}

Table II. Density of filipin-sterol complexes on the plasma membrane overlying the head and flagellum regions of the spermatozoon of Culex quinquefasciatus. Values are expressed in number of particles per bLm 2.

\begin{tabular}{lrrr}
\hline \multirow{2}{*}{ Sperm region } & \multicolumn{4}{c}{ Pilipin-sterol complexes } \\
& E-face & Total \\
\hline Head & $290 \pm 10$ & $175 \pm 22$ & $465 \pm 32$ \\
Flagellum & $72 \pm 16$ & $67 \pm 11$ & $139 \pm 27$ \\
\hline
\end{tabular}




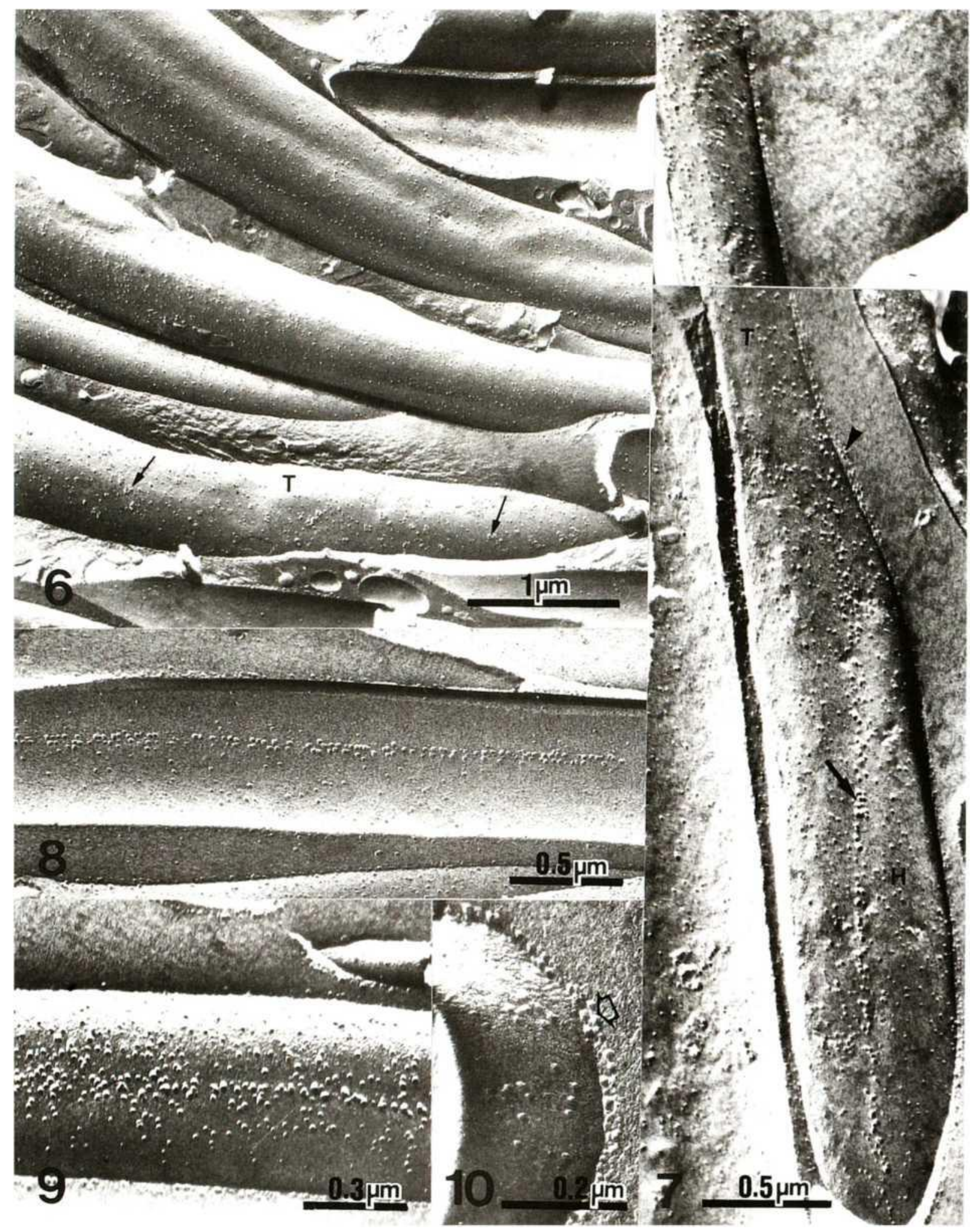

Figs 6-10. Freeze-fracture replicas of mosquito spermatozoa. 6. This micrograph shows the P- and E-fracture faces of the plasma membrane of several spermatozoa. Clusters of particles (arrows) are observed in the portion of the plasma membrane lining the tail region (T). $\mathrm{x} 27000$. 7. Freeze-fracture replica showing the sperm head $(\mathrm{H})$ and the initial tail portion $(\mathrm{T})$. The zipper-line (arrow) is located in the posterior region of the head and is not continuous. The plasma membrane overlying the initial tail portion shows randomly distributed intramembranous particles. The surface coat (arrowhead) appears as two rows of particles, x 46000. 8. The zipper-line is formed by two rows of particles associated with the E-face of the plasma membrane, x 40000. 9. The zipper-line is irregular but can be seen on the P-face of the plasma membrane, $x$ 60000. 10. Detail showing the surface coat (arrow), x 112500. 


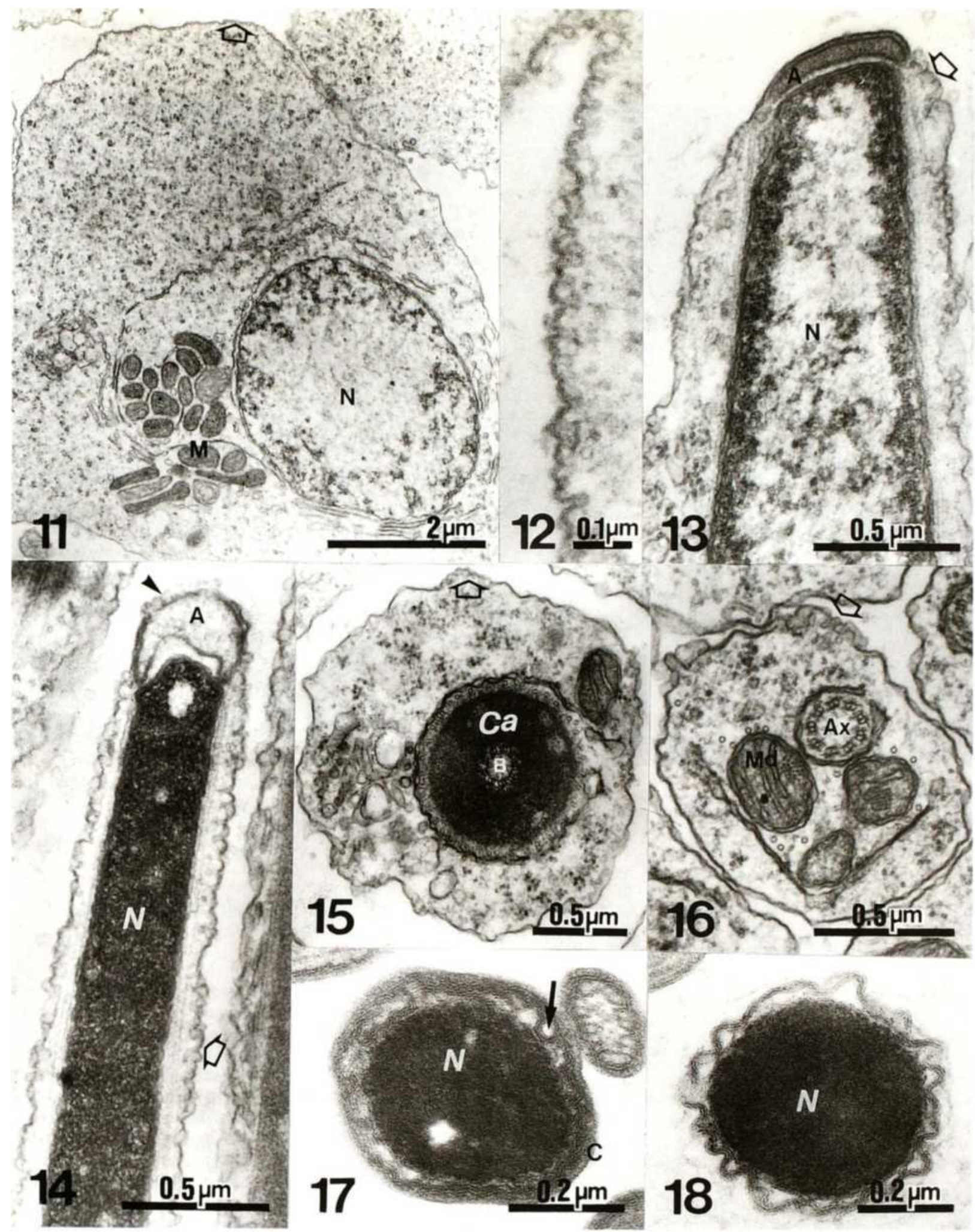

Figs 11 -18: Thin sections of filipin treated spermatid and spermatozoa. 11. Thin sections through the nuclear region $(\mathrm{N})$ of a spermatid showing the characteristic wavy configuration (arrow) induced by the formation of filipin-sterol complexes in the plasma membrane. M: mitochondria, x 13 500.12. Thin section showing a sterol-rich area of the spermatid plasma membrane, x 100000. 13. Longitudinal section through the spermatid head showing the characteristic wavy configuration (arrow) induced by the formation of filipin-sterol complexes in the plasma membrane lining the nuclear region $(\mathrm{N})$. These complexes were not seen in the acrosomal region (A), x 52000. 14. Longitudinal section through the head of a spermatid in final stage of différenciation. The plasma membrane lining the nuclear region (arrow) shows an uniform distribution of filipin-sterol complexes. In contrast, such complexes appeared only in some regions (arrowhead) of the membrane lining the acrosomal region. A: acrosome; $\mathrm{N}$ : nucleus, $\mathrm{x} 53$ 000. 15. Cross section of centriole adjunct (Ca) and basal body (B). The plasma membrane in that region shows few filipin-sterol complexes (arrow), x 33 000.16. Cross section of falgellum of the spermatid. The plasma membrane lining this region presents few filipin-sterol complexes (arrow). Ax: axoneme; Md: mitochondrial derivative, x 50000. 17. Crosssection showing the head of a spermatozoon found in the seminal vesicle. Filipin-sterol complexes are observed in the plasma membrane (arrow). C: Coat; N: nucleus, x 100000. 18. Cross section showing the head of a spermatozoon found in the spermatheca. Several filipin-sterol complexes are observed in the plasma membrane. $\mathrm{N}$ : nucleus, $\mathrm{x} 87000$. 


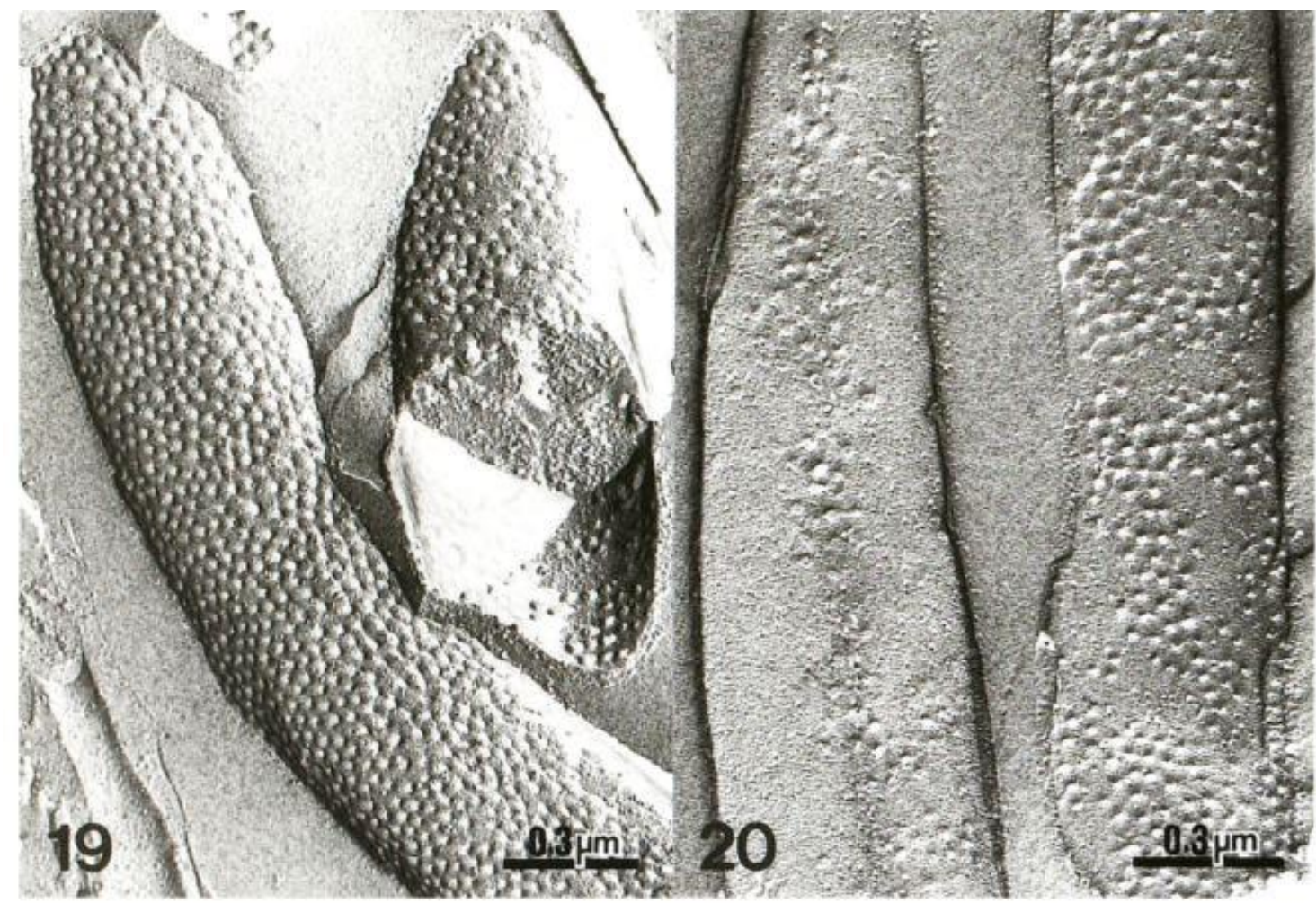

Figs 19, 20. Freeze-fracture replicas of filipin treated spermatozoa, 19. Numerous filipin-sterol complexes are distributed throughout the membrane lining the nuclear region, $x 60000$. 20. Aggregation of filipin-sterol complexes are observed in some regions of the tail. $\times 67500$.

\section{Discussion}

Studies carried out in the last years have shown that the spermatozoa are highly polarized cells presenting regional specializations of the plasma membrane. The evidence that the o ganization and composition of the plasma membrane varied between different regions of the sperm surface led to the concept that the sperm plasma is a mosaic of restricted domains that reflects the specialized functions of the surface of the spermatozoon. Its anterior region is specialized for recognition, exocytosis of enzyme contained in the acrosome and fusion with surface oocyte during fertilization, while the membrane lining the tail region plays some role in the control of cell motility. Studies have demonstrated that these domains are dynamic features that undergo changes in organization and composition during the processes of differentiation and maturation of the spermatids (for reviews, see $[14,27,30,40]$ ).

Our present observations show that the spermatozoon of Culex quinquefasciatus does not present membrane specializations similar to those found in the mammalian spermatozoon. In the spermatid the intramembranous particles are randomly distributed throughout its plasma membrane. However, during differentiation into the spermatozoon a 
regular arrangement of particles appears in the head region. It is interesting to note that two populations of particles were observed. The large particles are regularly arranged in double rows, as a zipper-line, which was mainly seen on the E-face of the sperm plasma membrane lining the head, probably in the postacrosomal region. Our suggestion about this localization of the zipper-line is due to the fact that it is always observed in the wider regions of the Culex quinquefasciatus spermatozoon (see fig 7). However, the small particles are randomly distributed on the P- and E-faces of the plasma membrane.

Specialized domains have been found in spermatozoon plasma membrane of some insects. A longitudinal row of membrane particles was previously observed in the plasma membrane of a fruit-fly sperm [5] but its location relative to the sperm surface could not be determined. The paired spermatozoa of the dytiscid beetles display on specialized domains of the cell membrane that are characterized by different patterns of intramembranous particles [10]. The zipper-line is evident in the hemipteran spermatozoon and was located in the tail region, between the axoneme and two mitochondrial derivatives [9]. It is possible that the zipper-line is a structure analogous to that of the zipper found in the principal piece of the mammalian sperm tail [14, 17-19].

Several functions have been suggested for the mare-malian zipper and hemipteran zipper-line. It may serve as a site of attachment of the plasma membrane to underlying structures. The particles may also form a channel for the transport of some metabolite $[9,10$, $17,19]$. However, the observation of the zipper-line in the postacrosomal region of the Culex quinquefasciatus spermatozoon suggests that this membrane domain may also play some role in sperm-oocyte recognition and fusion.

The establishment of surface domains during differentiation of the spermatid may also involve changes in the distribution of phospholipids and sterols. Previous studies have shown that cholesterol plays an important role in the regulation of membrane permeability, fluidity and enzymatic activity $[21,23,36]$.

Studies carried out in the last years have demonstrated that filipin, a polyenic antibiotic, interacts with 3-hydroxysterols, including cholesterol, producing aggregates which are visible as hemispherical bulges in thin sections of the plasma membrane or in freezefracture replicas $[11,28]$. The present study has revealed that the density and distribution of filipin-sterol complexes in the plasma membrane of mosquito spermatid undergo distinct changes during its differentiation. The filipin-sterol complexes are distributed in the whole plasma membrane of early spermatid. A change in distribution of filipin-sterol complexes occurs during differentiation of the spermatid, with the appearance of surface domains in the spermatozoon. The highest density of filipin-sterol complexes was observed in the plasma 
membrane covering the nuclear region. The plasma membrane of the acrosomal and flagellar regions also presents some filipin-sterol complexes. There are no previous studies on the distribution of cholesterol in the plasma membrane of insect sperm.

Previous studies carried out on mammalian spermatozoa have shown that the density of filipin-sterol complexes is higher in the acrosomal region than in the postacrosomal region, which usually is free of such complexes. The membrane lining the flagellum, however, presents a large number of randomly distributed filipin-sterol complexes which are more abundant in the membrane lining the middle piece [II, $23,36,38,39]$. The concentration and localization of cholesterol molecules in the membrane exert a marked influence on its physical state. Its presence tends to decrease the viscosity and to restrict the mobility of phospholipids and proteins. The regional differences observed in the distribution of cholesterol in the mosquito sperm membrane probably are due to specific functions played by some membrane domains, as already suggested for vertebrate spermatozoa $[21,23,36]$.

Therefore, in contrast to the situation of mammalian spermatozoon where the existence of various membrane domains in different cell regions has been well established, the Culex quinquefasciatus spermatozoon displays only a membrane, domain, the zipper-line localized in the postacrosomal region.

Acknowledgments

Thanks are due to $\mathrm{Dr}$ RL de Oliveira for supplying the mosquitoes, Mr S Cruz for his assistance in preparing the freeze-fracture replicas and Mr A Lisboa for assistance in preparing the micrographs. This work has been supported by Financiadora de Estudos e Projetos (FINEP), Conselho Nacional de Desenvolvimento Cientifico e Tecnol6gico (CNPq) and Coordena .o de Aperfei- Coamento de Pessoal de Nivel Superior (CAPES) 


\section{References}

Aguas AP, Pinto da Silva P (1984) High density of transmembrane glycoproteins on the flagellar surface of boar sperm cells. J Cell Biol 99, 655-660

Baccetti B (1972) Insect sperm cells. Adv Insect Physiol 9, 315 - 397

Baccetti B, Afzelius BA (1976) The Biology of the Sperm Cell, Karger Basel, New York, $354 p$

Baccetti B, Bigliardi E, Burrini AG (1978) The cell surface during mammalian spermiogenesis. Dev Biol 63, 187 - 196

Baccetti B, Bigliardi E, Rosati F (1971) The spermatozoon of Arthropoda XIII. The cell surface. J Ultrastruct Res 35, $582-605$

Bao SN, De Souza W (1991) Ultrastructural and cytochemical studies of the spermatid and spermatozoon of Culex quinquefasciatus (Culicidae). J Submicrosc Cytol Pathol, in press

Brown CR, Von Glos KI, Jones R (1983) Changes in plasma membrane of rat spermatozoa during maturation in the epididymis. J Cell Biol 96, 256- 264

Cooper GW, Bedford JM (1971) Acquisition of surface charge by the plasma membrane of mammalian spermatozoa during epididymal maturation. Anat Rec 169, 300- 301

Dallai R, Afzelius BA (1982) On zipper-lines or particle arrays within the plasma membrane of hemipteran spermatozoa (Heteroptera, Insecta), J Ultrastruct Res 80, 197 - 205

Dallai R, Afzelius BA (1985) Membrane specializations in the paired spermatozoa of dytiscid water beetles. Tiss Cell 17, 561-572

Elias PM, Friend DS, Goerke J (1979) Membrane sterol heterogeneity: freeze-fracture detection with saponins and filipin. J Histochem Cytochem 27, 1247- 1260

Esponda P (1985) Spermiogenesis and Spermatozoa in Mammals Servicio Editorial Universidad Del Pais Vasco, Madrid, $84 \mathrm{p}$

Evans RW, Setchell BP (1979) Lipid changes in boar spermatozoa during epididymal maturation with some observations on the flow and composition of boar fete testis fluid. J Reprod Fert 57, 189- 199

Fawcett DW (1975) The mammalian spermatozoon, Dev Biol 44, 394-436

Feutcher FA, Vernon RB, Eddy EM (1981) Analysis of the sperm surface with monoclonal antibodies : topographically restricted antigens appearing in the epididymis. Biol Reprod 24, 1099- III0

Forsman CA, Pinto da Silva P (1989) Surface views of spermatozoa as revealed by fracture-flip. J Cell Sci 92, 415- 426 
Friend DS, Elias PM, Rudolf J (1979) Disassembly of the guinea pig sperm tail. In: The Spermatozoon (Fawcett DW, Bedford JM, eds) Urban and Schwarzenberg, Inc, Baltimore, Munich, 157- 168

Friend DS, Fawcett DW (1974) Membrane differentiations in freeze-fractured mammalian sperm. J Cell Bio163,641 -664

Friend DS, Heuser J (1981) Ordely particle arrays on the mitochondrial outer membrane in rapidly-frozen sperm. Anat Rec 199, 159- 175

Gordon M, Dandekar PV, Bartoszewicz W 0975) The surface coat of epididymal ejaculated and capacitated sperm. J Ulstrastruct Res 50, 199-207

Kessel RG, Tung HN, Roberts R (1985) Filipin-sterol complexes in the plasma membrane of zebrafish spermatozoa. Anat Rec 212, 358-363

Legault J, Bouthillier M, Bleau G, Chapdelaine A, Roberts KD 0979) The sterol and sterol sulfate content of the male hamster reproductive tract. Biol Reprod 20, 1213- 1219

Lopez ML, De Souza W (1991) Distribution of filipin-sterol complexes in the plasma membrane of stallion spermatozoa during the epididymal maturation process. Mol Reprod Dev 28, 158168

Lopez ML, De Souza W, Bustos OE (1987) Cytochemical analysis of the anionic sites on the membrane of the stallion spermatozoa during the epidymal transit. Gamete Res 18, 319- 332 